\title{
Trends of cervical cancer at global, regional, and national level: data from the Global Burden of Disease study 2019
}

\section{Xingxing Zhang}

Nanfang Hospital,Southern Medical University

Danfeng Yu

Department of MICU, Guangdong Women and Children Hospital

\section{Wenwen Cai}

Nanfang Hospital,Southern Medical University

Weiqing Ruan ( $\sim$ jamela@sina.com )

Nanfang Hospital,Southern Medical University

\section{Research Article}

Keywords: Cervical cancer, Global burden of disease, Age-standardized rate, Estimated annual percentage change, Epidemiological trend

Posted Date: February 18th, 2021

DOl: https://doi.org/10.21203/rs.3.rs-195932/v1

License: (c) (i) This work is licensed under a Creative Commons Attribution 4.0 International License. Read Full License 


\section{Abstract \\ Background}

Cervical cancer remains an important global health problem. This article aims to analysis the trend of cervical cancer at global, regional, and national level from 1990 to 2019, which would inform the health decision-making.

\section{Methods}

Data on cervical cancer was extracted from the Global Burden of Disease study 2019. The trends of cervical cancer burden were estimated using estimated annual percentage change (EAPC) and agestandardized rate (ASR).

\section{Results}

Globally, the decreasing trends in incidence, death, and disability adjusted life years (DALYs) of cervical cancer were observed worldwide from 1990 to 2019, with the respective EAPCs were -0.38 (95\% confidence interval [Cl]: -0.41 to -0.34 ), -0.93 ( $95 \% \mathrm{Cl}:-0.98$ to -0.88 ), and -0.95 (95Cl\%: -1.00 to -0.90 ). Meanwhile, decreasing trends were also seen in most sociodemographic index (SDI) areas and geographic regions, particularly the trends of death and DALYs in Central Latin America, in which the respective EAPCs were -2.61 (95\% Cl: -2.76 to -2.46$)$ and $-2.48(95 \% \mathrm{Cl}$ : -2.63 to -2.32$)$. However, pronounced increasing trends occurred in the incidence in East Asia (EAPC $=1.33 ; 95 \% \mathrm{Cl}$ : 1.12 to 1.55$)$. At the national level, the decreasing trends of cervical cancer were observed in most countries/territories, particularly the DALYs in Maldives (EAPC $=-5.06 ; 95 \% \mathrm{Cl}$ - -5.40 to -4.72 ). Whereas increasing trend were seen in Lesotho, Zimbabwe, and Bulgaria.

\section{Conclusions}

Slowly decreasing trends of cervical cancer were demonstrated worldwide from 1990 to 2019. Cervical cancer remains a substantial health problem globally, which required the more effective prevention and control strategies.

\section{Introduction}

Cervical cancer is the fourth leading cause of cancer death among women worldwide [1, 2]. It was estimated that 570,000 new cases added and 311,000 women died by cervical cancer globally in 2018[3], particularly middle-aged women [4]. 
The distribution of cervical cancer differ throughout the world,more than $85 \%$ of these deaths occurring in developing regions[5]. It is reported that over $90 \%$ of the highest incidence rate of cervical cancer occurs in sub-Saharan Africa [6]. Attributed to the effective Papanicolaou (Pap) test and improving prevention of the human papilloma virus (HPV), drastic change in the epidemiological pattern of cervical cancer had made over the past decades[7]. For example, Finland launched an nationwide screening programmer for cervical cancer in 1960, which led to a steep decrease in the rate since 1973 (below 1/100,000) [8].

Australia has established an HPV vaccination program covering more than $70 \%$ of girls and boys aged 12-13 years nationwide, and the high-grade cervical dysplasia of women under 18 has been reduced by $38 \%$ [9]. On the contrary, the incidence of cervical cancer in the former Soviet Union has risen significantly, in where existed the weak health care systems and inadequate screening program[10]. Currently, three types of prophylactic vaccines, bivalent HPV vaccine, quadrivalent, and the 9-valent formulation have been approved for use in many countries[11], and it was estimated that the increasing coverage of vaccine would greatly promote the decline in incidence and death of cervical cancer [12].

In conclusion, the epidemiological patterns of cervical cancer had changed dramatically over the past decades, which emphasized the importance to track its changing trends. Therefore, the authors estimated the global, regional and national trends of cervical cancer from 1990 to 2019 using the data from the latest version of GBDs, would inform the health strategies.

\section{Methods}

\section{Data source}

Data on cervical cancer burden including incidence, death, and DALYs, were explored using the Global Health Data Exchange (GHDx) query tool (http://ghdx.healthdata.org/gbd-results-tool). Data was extracted by age, SDI areas and geographic regions, and countries from 1990 to 2019, without any inclusion/exclusion criteria. According to sociodemographic Index (SDI), regions and countries was classified into 5 categories: low, low-middle, middle, high-middle, and high. The data was available in 21 geographic regions and 204 countries/territories worldwide. Data on the Human Development Index (HDI) were obtained from the United Nations Development Program (http://hdr.undp.org/en /data).

\section{Statistical analysis}

Age-standardized is a necessary method when considering differences in the age structure of multiple populations over time. The age-standardized rate (ASR) is estimated using the following formula:

$$
\mathrm{ASR}=\frac{\sum_{i=1}^{A} a_{i} w_{i}}{\sum_{i=1}^{A} w_{i}} \times 100,000
$$

Thereinto, $a_{i}$ represents the age-specific rate in the $i^{\text {th }}$ age group, $w$ represents the number of people (or the weight) in the respective $i^{\text {th }}$ age group from among the selected standard population, and $A$ represents the number of age groups. 
The estimated annual percentage change (EAPC) is a widely accepted index to quantify and describe the trend of ASR[13]. A regression line is fitted to the natural logarithm of the rates. The EAPC and its $95 \%$

confidence interval $(\mathrm{Cl})$ were estimated using the linear regression model. The formulas were described as following:

$y=a+\beta x+\varepsilon$,

$\operatorname{EAPC}=100 \times(\exp (\beta)-1)$

where $y=\ln (A S R)$ and $x=$ calendar year. Trends were assessed as follows: 1 . if EAPC and its $95 \% \mathrm{Cl}>0$ signified an increasing trend in ASR; 2 . If EAPC value and its $95 \% \mathrm{Cl}<0$ signified a decreasing trend in ASR; 3. other outcomes signified that ASR was stable over time. In order to explore the impact factors of EAPC, the relations between EAPCs and ASR in 1990, and between EAPCs and HDI in 2019, were calculated using the Pearson correlation analysis. Data were analyzed using an R program (Version 3.6.2).

\section{Results}

\section{Trends in incidence of cervical cancer}

The incident cases of cervical cancer in the world were $565.54 \times 10^{3}\left(95 \% \mathrm{UI}: 481.52 \times 10^{3}\right.$ to $\left.636.43 \times 10^{3}\right)$ in 2019 , with an increase of $68.50 \%$ since 1990 . The overall age-standardized incidence rate (ASIR) showed a downward trend between 1990 and 2019, with an annual average of $0.38 \%$ per year $(\mathrm{EAPC}=-0.38 ; 95 \% \mathrm{Cl}$ : -0.41 to -0.34 ; Table 1 and Fig. 1). Increasing percentage changes in number were seen in all age groups, and the highest ones were those aged above 80 (118.81\%) and 50-54 (90.42\%) years (Supplementary table 1 and Fig. 2A). Meanwhile, decreasing trends were appeared in all SDI areas, particularly high SDI areas (EAPC $=-0.95 ; 95 \% \mathrm{Cl}:-1.05$ to -0.85 ; Table 1 and Fig. 2B). In geographic regions, East Asia $\left(115.38 \times 10^{3}\right)$ has the largest number of cases in 2019 (Table 1). The incidence of cervical cancer were decreasing in most areas, and the most pronounced ones were Central Latin America (EAPC $=-1.77 ; 95 \% \mathrm{Cl}$ : -1.92 to -1.62), followed by Tropical Latin America and South Asia. Increasing trends only occurred in East Asia and Southern Sub-Saharan Africa, in which EAPCs were $1.33(95 \% \mathrm{Cl}: 1.12$ to 1.55$)$ and 0.28 respectively ( $95 \% \mathrm{Cl}: 0.06$ to 0.51 ; Table 1 and Fig. 2C). Among 204 countries/territories, the highest ASR in 2019 in Kiribati (108.8 per 1000), and lowest in Egypt (2.84 per 1000; Fig. 3A), largest increase in the incident number was occurred in United Arab Emirates (501.27\%) and Saudi Arabia (453.6\%). Conversely, the largest decrease was observed in Denmark (-46.30\%) and Latvia (-45.66\%; Supplementary table 2 and Fig. 3B). The ASIR of cervical cancer showed decreasing trends in 151 countries/territories, and the largest ones were seen in Maldives, Taiwan, and Singapore, in which the respective EAPCs were $-3.68(95 \% \mathrm{Cl}$ : -4.00 to -3.35$)$, -3.63 (95\% Cl: -3.96 to -3.30$)$, and -3.40 (95\% Cl: -3.61 to -3.18$)$. On the other hand, increasing trends were observed in 28 countries, particularly Lesotho, Italy, and China, with the respective EAPCs were 3.43 ( $95 \% \mathrm{Cl}: 2.90$ to 3.95), 2.02 (95\%Cl: 1.70 to 2.34 ), and 1.61 (95\% Cl: 1.36 to 1.86;

Supplementary table 2 and Fig. 3C). 
Table 1

The number and age-standardized rate of cervical cancer incidence in global, sexes, SDI areas and geographic regions in 1990 and 2019, and percentage change of absolute number and the EAPCs from 1990 to 2019

\begin{tabular}{|c|c|c|c|c|c|c|}
\hline & 1990 & & 2019 & & $1990-20$ & \\
\hline Characteristics & $\begin{array}{l}\text { Number } \\
\times 10^{3} \\
(95 \% \text { UI) }\end{array}$ & $\begin{array}{l}\text { ASR/100,000) } \\
(95 \% \mathrm{UI})\end{array}$ & $\begin{array}{l}\text { Number } \\
\times 10^{3} \\
(95 \% \text { UI) }\end{array}$ & $\begin{array}{l}\text { ASR/100,000) } \\
(95 \% \mathrm{UI})\end{array}$ & $\begin{array}{l}\text { Change } \\
\text { in } \\
\text { number } \\
(\%)\end{array}$ & $\begin{array}{l}\text { EAPC } \\
(95 \% \mathrm{Cl})\end{array}$ \\
\hline Overall & $\begin{array}{l}335.64 \\
(300.35- \\
393.89)\end{array}$ & $\begin{array}{l}14.91 \\
(13.37- \\
17.55)\end{array}$ & $\begin{array}{l}565.54 \\
(481.52- \\
636.43)\end{array}$ & $\begin{array}{l}13.35 \\
(11.37- \\
15.03)\end{array}$ & 68.50 & $\begin{array}{l}-0.38 \\
(-0.41--0.34)\end{array}$ \\
\hline SDI & & & & & & \\
\hline Low & $\begin{array}{l}41.50 \\
(31.77- \\
50.80)\end{array}$ & $\begin{array}{l}27.74 \\
(21.56- \\
34.25)\end{array}$ & $\begin{array}{l}78.82 \\
(61.61- \\
97.93)\end{array}$ & $\begin{array}{l}23.21 \\
(18.31- \\
28.76)\end{array}$ & 89.94 & $\begin{array}{l}-0.69 \\
(-0.73--0.65)\end{array}$ \\
\hline Low-middle & $\begin{array}{l}66.22 \\
(54.06- \\
81.76)\end{array}$ & $\begin{array}{l}18.04 \\
(14.86- \\
22.49)\end{array}$ & $\begin{array}{l}125.96 \\
(107.88- \\
150.11)\end{array}$ & $\begin{array}{l}15.78 \\
(13.57- \\
18.87)\end{array}$ & 90.23 & $\begin{array}{l}-0.56 \\
(-0.65--0.47)\end{array}$ \\
\hline Middle & $\begin{array}{l}92.18 \\
(81.45- \\
116.40)\end{array}$ & $\begin{array}{l}14.87 \\
(13.17- \\
18.85)\end{array}$ & $\begin{array}{l}183.34 \\
(144.49- \\
208.86)\end{array}$ & $\begin{array}{l}13.44 \\
(10.61- \\
15.28)\end{array}$ & 98.89 & $\begin{array}{l}-0.29 \\
(-0.33--0.24)\end{array}$ \\
\hline High-middle & $\begin{array}{l}75.80 \\
(71.53- \\
88.88)\end{array}$ & $\begin{array}{l}12.77 \\
(12.05-15)\end{array}$ & $\begin{array}{l}113.12 \\
(89.78- \\
129.15)\end{array}$ & $\begin{array}{l}11.59 \\
(9.18-13.24)\end{array}$ & 49.23 & $\begin{array}{l}-0.27 \\
(-0.31--0.22)\end{array}$ \\
\hline High & $\begin{array}{l}59.69 \\
(54.3- \\
61.65)\end{array}$ & $\begin{array}{l}11.83 \\
(10.67- \\
12.22)\end{array}$ & $\begin{array}{l}63.86 \\
(55.71- \\
71.45)\end{array}$ & $\begin{array}{l}8.91 \\
(7.74-9.99)\end{array}$ & 6.99 & $\begin{array}{l}-0.95 \\
(-1.05--0.85)\end{array}$ \\
\hline Regions & & & & & & \\
\hline East Asia & $\begin{array}{l}45.26 \\
(35.38- \\
79.36)\end{array}$ & $\begin{array}{l}9.00 \\
(7.08-15.63)\end{array}$ & $\begin{array}{l}115.38 \\
(64.35- \\
147.12)\end{array}$ & $\begin{array}{l}11.17 \\
(6.25-14.26)\end{array}$ & 154.94 & $\begin{array}{l}1.33 \\
(1.12-1.55)\end{array}$ \\
\hline
\end{tabular}

EAPC: estimated annual percentage change; ASR, age-standardized rate; $\mathrm{Cl}$, confidence interval; UI: uncertainty interval; SDI: socio-demographic index. Percentage change in absolute number was calculated based on the crew data. 


\begin{tabular}{|c|c|c|c|c|c|c|}
\hline \multirow{2}{*}{ South Asia } & \multicolumn{2}{|l|}{1990} & \multicolumn{2}{|l|}{2019} & \multicolumn{2}{|c|}{ 1990-2019 } \\
\hline & 56.36 & 16.04 & 100.02 & 12.37 & 77.48 & -1.09 \\
\hline & $\begin{array}{l}(44.21- \\
68.59)\end{array}$ & $\begin{array}{l}(12.64- \\
19.66)\end{array}$ & $\begin{array}{l}(80.11- \\
124.77)\end{array}$ & $(9.94-15.46)$ & & $(-1.29--0.90)$ \\
\hline \multirow{2}{*}{$\begin{array}{l}\text { Southeast } \\
\text { Asia }\end{array}$} & 31.13 & 18.75 & 52.06 & 14.48 & 67.26 & -1.06 \\
\hline & $\begin{array}{l}(23.52- \\
38.68)\end{array}$ & $(14.3-23.63)$ & $\begin{array}{l}(41.93- \\
68.67)\end{array}$ & $(11.73-19)$ & & $(-1.17--0.96)$ \\
\hline \multirow[t]{2}{*}{ Central Asia } & 5.27 & 18.58 & 7.67 & 16.00 & 45.34 & -0.34 \\
\hline & $\begin{array}{l}(4.9- \\
5.63)\end{array}$ & $\begin{array}{l}(17.37- \\
19.85)\end{array}$ & $\begin{array}{l}(6.65- \\
8.83)\end{array}$ & $(13.94-18.4)$ & & $(-0.45--0.23)$ \\
\hline High-income & 12.47 & 11.65 & 15.06 & 10.33 & 20.82 & -0.17 \\
\hline Asia Pacific & $\begin{array}{l}(11.64- \\
14.36)\end{array}$ & $\begin{array}{l}(10.81- \\
13.42)\end{array}$ & $\begin{array}{l}(11.91- \\
17.96)\end{array}$ & $(7.99-12.4)$ & & $(-0.27--0.06)$ \\
\hline \multirow[t]{2}{*}{ Oceania } & 0.57 & 29.58 & 1.33 & 28.22 & 133.17 & -0.05 \\
\hline & $\begin{array}{l}(0.4- \\
0.76)\end{array}$ & $\begin{array}{l}(21.39- \\
39.83)\end{array}$ & $\begin{array}{l}(0.86- \\
1.82)\end{array}$ & $(19-38.09)$ & & $(-0.12-0.03)$ \\
\hline \multirow[t]{2}{*}{ Australasia } & 1.37 & 11.83 & 1.65 & 8.22 & 20.06 & -0.98 \\
\hline & $\begin{array}{l}(1.15- \\
1.47)\end{array}$ & $(9.76-12.65)$ & $\begin{array}{l}(1.27- \\
2.11)\end{array}$ & $(6.32-10.59)$ & & $(-1.36--0.6)$ \\
\hline \multirow{2}{*}{$\begin{array}{l}\text { Eastern } \\
\text { Europe }\end{array}$} & 22.82 & 14.53 & 23.00 & 14.76 & 0.77 & 0.03 \\
\hline & $\begin{array}{l}(19.67- \\
24.65)\end{array}$ & $\begin{array}{l}(12.66- \\
15.79)\end{array}$ & $\begin{array}{l}(18.91- \\
28.03)\end{array}$ & $\begin{array}{l}(11.91- \\
18.14)\end{array}$ & & $(-0.12-0.18)$ \\
\hline \multirow{2}{*}{$\begin{array}{l}\text { Western } \\
\text { Europe }\end{array}$} & 28.60 & 11.19 & 27.17 & 8.26 & -4.99 & -0.97 \\
\hline & $\begin{array}{l}(25.91- \\
29.68)\end{array}$ & $(9.88-11.62)$ & $\begin{array}{l}(22.69- \\
31.7)\end{array}$ & $(6.85-9.68)$ & & $(-1.07--0.88)$ \\
\hline \multirow[t]{2}{*}{ Central Europe } & 15.39 & 20.67 & 13.68 & 15.80 & -11.14 & -1.08 \\
\hline & $\begin{array}{l}(14.39- \\
16.21)\end{array}$ & $\begin{array}{l}(19.23- \\
21.74)\end{array}$ & $\begin{array}{l}(11.26- \\
15.9)\end{array}$ & $\begin{array}{l}(12.97- \\
18.48)\end{array}$ & & $(-1.21--0.96)$ \\
\hline \multirow{2}{*}{$\begin{array}{l}\text { High-income } \\
\text { North America }\end{array}$} & 17.53 & 10.39 & 21.85 & 8.93 & 24.65 & -0.58 \\
\hline & $\begin{array}{l}(15.11- \\
18.26)\end{array}$ & $(8.89-10.83)$ & $\begin{array}{l}(17.42- \\
26.62)\end{array}$ & $(7.09-10.93)$ & & $(-0.71--0.44)$ \\
\hline
\end{tabular}

EAPC: estimated annual percentage change; ASR, age-standardized rate; $\mathrm{Cl}$, confidence interval; Ul: uncertainty interval; SDI: socio-demographic index. Percentage change in absolute number was calculated based on the crew data. 


\begin{tabular}{|c|c|c|c|c|c|c|}
\hline \multicolumn{3}{|c|}{1990} & \multicolumn{2}{|l|}{2019} & \multicolumn{2}{|c|}{ 1990-2019 } \\
\hline \multirow{2}{*}{$\begin{array}{l}\text { Andean Latin } \\
\text { America }\end{array}$} & 4.10 & 33.39 & 9.10 & 29.74 & 121.97 & -0.53 \\
\hline & $\begin{array}{l}(3.45- \\
4.86)\end{array}$ & $\begin{array}{l}(28.20- \\
39.63)\end{array}$ & $\begin{array}{l}(6.93- \\
11.61)\end{array}$ & $\begin{array}{l}(22.67- \\
37.83)\end{array}$ & & $(-0.66--0.41)$ \\
\hline \multirow{2}{*}{$\begin{array}{l}\text { Central Latin } \\
\text { America }\end{array}$} & 17.08 & 32.30 & 28.48 & 21.45 & 66.74 & -1.77 \\
\hline & $\begin{array}{l}(15.8- \\
17.85)\end{array}$ & $\begin{array}{l}(29.43- \\
33.73)\end{array}$ & $\begin{array}{l}(23.11- \\
35.03)\end{array}$ & $\begin{array}{l}(17.44- \\
26.37)\end{array}$ & & $(-1.92--1.62)$ \\
\hline \multirow[t]{2}{*}{ Caribbean } & 4.12 & 28.00 & 6.86 & 26.23 & 66.57 & -0.24 \\
\hline & $\begin{array}{l}(3.33- \\
4.72)\end{array}$ & $\begin{array}{l}(22.69- \\
31.86)\end{array}$ & $\begin{array}{l}(5.36- \\
8.50)\end{array}$ & $\begin{array}{l}(20.41- \\
32.58)\end{array}$ & & $(-0.30--0.19)$ \\
\hline \multirow{2}{*}{$\begin{array}{l}\text { Tropical Latin } \\
\text { America }\end{array}$} & 14.12 & 24.52 & 23.74 & 17.91 & 68.15 & -1.29 \\
\hline & $\begin{array}{l}(13.36- \\
16.36)\end{array}$ & $\begin{array}{l}(23.12- \\
28.28)\end{array}$ & $\begin{array}{l}(22.13- \\
27.18)\end{array}$ & $\begin{array}{l}(16.69- \\
20.43)\end{array}$ & & $(-1.39--1.19)$ \\
\hline \multirow{2}{*}{$\begin{array}{l}\text { Southern Latin } \\
\text { America }\end{array}$} & 6.48 & 26.30 & 9.84 & 24.85 & 51.93 & -0.38 \\
\hline & $\begin{array}{l}(6.05- \\
6.87)\end{array}$ & $\begin{array}{l}(24.53- \\
27.91)\end{array}$ & $\begin{array}{l}(7.27- \\
12.85)\end{array}$ & $\begin{array}{l}(18.23- \\
32.74)\end{array}$ & & $(-0.52--0.25)$ \\
\hline Eastern Sub- & 19.08 & 38.27 & 36.33 & 31.79 & 90.43 & -0.80 \\
\hline $\begin{array}{l}\text { Saharan } \\
\text { Africa }\end{array}$ & $\begin{array}{l}(14.41- \\
23.81)\end{array}$ & $\begin{array}{l}(28.81- \\
47.55)\end{array}$ & $\begin{array}{l}(25.76- \\
48.45)\end{array}$ & $(22.9-41.68)$ & & $(-0.87--0.73)$ \\
\hline Southern Sub- & 6.17 & 33.33 & 12.02 & 32.90 & 94.80 & 0.28 \\
\hline $\begin{array}{l}\text { Saharan } \\
\text { Africa }\end{array}$ & $\begin{array}{l}(4.68- \\
7.53)\end{array}$ & $\begin{array}{l}(25.19- \\
40.62)\end{array}$ & $\begin{array}{l}(9.74- \\
14.44)\end{array}$ & $\begin{array}{l}(26.88- \\
39.48)\end{array}$ & & $(0.06-0.51)$ \\
\hline Western Sub- & 14.85 & 28.64 & 33.37 & 25.47 & 124.75 & -0.35 \\
\hline $\begin{array}{l}\text { Saharan } \\
\text { Africa }\end{array}$ & $\begin{array}{l}\text { (11.66- } \\
18.64)\end{array}$ & $(22.59-35.8)$ & $\begin{array}{l}(26.14- \\
42.54)\end{array}$ & $\begin{array}{l}(20.17- \\
31.94)\end{array}$ & & $(-0.40--0.31)$ \\
\hline North Africa & 7.00 & 6.90 & 14.63 & 5.78 & 107.98 & -0.63 \\
\hline $\begin{array}{l}\text { and Middle } \\
\text { East }\end{array}$ & $\begin{array}{l}3(5.03- \\
8.03)\end{array}$ & $(4.92-7.88)$ & $\begin{array}{l}(11.14- \\
17.63)\end{array}$ & $(4.43-6.89)$ & & $(-0.72--0.54)$ \\
\hline Central Sub- & 5.84 & 37.38 & 12.30 & 32.32 & 110.47 & -0.51 \\
\hline $\begin{array}{l}\text { Saharan } \\
\text { Africa }\end{array}$ & $\begin{array}{l}(3.95- \\
7.83)\end{array}$ & $\begin{array}{l}(25.91- \\
49.42)\end{array}$ & $\begin{array}{l}(8.23- \\
16.88)\end{array}$ & $\begin{array}{l}(21.74- \\
44.74)\end{array}$ & & $(-0.61--0.41)$ \\
\hline
\end{tabular}




\section{Trends in death caused by cervical cancer}

The overall death number of cervical cancer was $184.53 \times 10^{3}$ (95\%UI: $164.84 \times 10^{3}$ to $218.94 \times 10^{3}$ ) in 2019 , with a $52.00 \%$ increase since 1990. The age-standardized death rate (ASDR) showed a decreasing trend from 1990 to 2019, with an annual average of $0.93 \%$ per year (EAPC $=-0.93 ; 95 \% \mathrm{Cl}$ : -0.98 to -0.88 ;

Supplementary table 3 and Fig. 1). Decreasing percentage changes were found in younger age groups, and the highest ones were those aged $15-19$ years (-23.71\%; Supplementary table 1 and Supplementary Fig. 1A). The ASDR in all SDI areas showed a downward trend, especially the high SDI areas (EAPC=-1.57; 95\% Cl: -1.68 to -1.46 ; Supplementary table 3 and Supplementary Fig. 1B). Geographically, the largest number of deaths was observed in South Asia $\left(1833.69 \times 10^{3}\right)$ in 2019 (Supplementary table 3). Downward trends were observed in most regions, especially Central and Latin America (EAPC $=-2.61 ; 95 \% \mathrm{Cl}$ : -2.76 to -2.46), followed by Tropical Latin America and Western Europe. Increasing trends only occurred in Southern Sub-Saharan Africa, in which EAPCs were 0.46 (95\% Cl: 0.19 to 0.72 ; Supplementary table 3 and Supplementary Fig. 1C). Among 204 countries/territories, the highest ASR in 2019 in Kiribati (69.52 per 1000), and lowest in Kuwait (1.76 per 1000; Supplementary Fig. 3A), the most significant increase in death number was noted in in United Arab Emirates (349.67\%) and Guatemala (276.37\%). In other words, the largest decrease was observed in Ukraine (-50.7\%) and Denmark (-48.58\%; Supplementary table 4 and Supplementary Fig. 3B). Decreasing trends of ASDR was showed in 174 countries/territories, particularly Maldives, Taiwan, and Singapore, in which the respective EAPCs were -4.54 (95\% Cl: -4.86 to -4.22$),-4.13$ (95\% Cl: -4.44 to -3.82$)$, and $-4.04(95 \% \mathrm{Cl}:-4.26$ to -3.81$)$. Conversely, increasing trends were observed in 30 countries, notably Lesotho, Zimbabwe and Bulgaria, with the respective EAPCs were 3.25 ( $95 \% \mathrm{Cl}: 2.72$ to 3.77), 1.46 ( $95 \% \mathrm{Cl}: 0.95$ to 1.97 ), and 1.20 (95\% Cl: 0.92 to 1.48 ; Supplementary table 4 and Supplementary Fig. 3C).

\section{Trends in DALYs caused by cervical cancer}

During the period 1990-2019, the number of DALYs caused by cervical cancer increased $44.99 \%$, and it was $8955.01 \times 10^{3}$ (95\% Ul: $7547.73 \times 10^{3}$ to $9978.46 \times 10^{3}$ ) in 2019 . The ASR of DALYs had a downward trend from 1990 to 2019 , with an annual average of $0.95 \%$ (EAPC $=-0.95 ; 95 \% \mathrm{Cl}:-1.00$ to -0.90 ;

Supplementary table 5 and Fig. 1). Decreasing percent changes of DALYs occurred in younger group, with the largest one was in the group aged 15-19 (-22.89\%; Supplementary table 1 and Supplementary Fig. 2A). DALYs of cervical cancer showed decreasing trends in all SDI areas, particularly high SDI areas (EAPC=-1.62; 95\% Cl: -1.74 to -1.49; Supplementary table 5 and Supplementary Fig. 2B). At regional level, the greatest number of DALYs was found in South Asia $\left(1833.69 \times 10^{3}\right)$ in 2019 (Supplementary table 5). The ASR of DALYs had decreasing trends in most regions, particularly Central Latin America (EAPC=-2.48; 95\%Cl: -2.63 to -2.32 ), followed by Tropical Latin America Latvia (EAPC=-1.95; 95\%Cl: -2.05 to -1.85 ) and Australasia (EAPC=-1.83; 95\% Cl: -2.26 to -1.41 ). Increasing trends only occurred in East Asia and Southern Sub-Saharan Africa, in which respective EAPCs were 0.02 (95\% Cl: -0.20 to 0.24$)$ and 0.23 ( $95 \% \mathrm{Cl}:-0.04$ to 0.51; Supplementary table 5 and Supplementary Fig. 2C). Among 204 countries/territories, the highest ASR in 2019 in Kiribati (2143.06 per 1000), and lowest in Kuwait (44.34 per 1000; Supplementary Fig. 4A), the largest increase in United Arab Emirates (409.36\%), Qatar (264.9\%) and Guatemala (264.9\%). Conversely, 
the largest decrease was observed in Denmark (-46.30\%), Latvia (-45.66\%) and Ukraine (-50.22\%;

Supplementary table 6 and Supplementary Fig. 4B). In generally, DALYs of cervical cancer were decreasing in 177 countries, and the most obvious downward trend was Maldives (EAPC=-5.06; 95\%Cl: -5.4 to -4.72 ), followed by Taiwan (EAPC=-4.43; 95\%Cl: -4.76 to -4.11 ), Singapore (EAPC=-4.31; $95 \% \mathrm{Cl}:-4.55$ to -4.07 ). By contrary, increasing trends were observed in 27 countries, specifically Lesotho, Zimbabwe and Bulgaria with the respective EAPCs were 3.44 (95\%Cl: 2.87 to 4.02$), 1.67$ (95\% Cl: 1.09 to 2.26 ) and 1.23 (95\% Cl: 0.95 to 1.51; Supplementary table 6 and Supplementary Fig. 4C).

\section{Analysis on the influential factors of EAPC}

During the period 1990-2019, EAPCs had positive associations with the ASR in 1990 in death and DALYs of cervical cancer ( $\rho=0.16, P=0.02 ; \rho=0.15, P=0.034$, respectively) (Fig. 4A-B). Whereas EAPCs had negative associations with the HDI in 2019 in incidence, death, and DALYs of cervical cancer $(\rho=-0.29, P<$ $0.001 ; \rho=0.42, P<0.001 ; \rho=0.39, p<0.001$, respectively) (Fig. 5A-C).

\section{Discussion}

Decreasing trends of cervical cancer were observed worldwide from 1990 to 2019 . The declining trends were predominantly a result of effective precautionary procedures combined with a series of sociocultural factors, including access to health care, changes in marriage age and family planning behavior, and enhancements in education level[14].

Cervical cancer occurred across a range of ages, our data showed the group aged 50-54 had the largest number of cases, suggesting infection at a younger age and slow progression to cancer[15]. The decreasing incident rate of cervical cancer in young women owe to the increasing coverage of vaccination against common subtypes of HPV[16]. However, the decreasing trends were slow, which probably related with behavioral factors, including smoking, using oral contraception, and impurity sexual behaviors [1719]

Mortality from cervical cancer is the malignancy with the largest inter-country range of variation among all cancers [20]. The morbidity of cervical cancer is closely related to the socioeconomic level. The morbidity of cervical cancer was the highest in developed countries, e.g. Southern Sub-Saharan Africa in 2019, explained by limited knowledge, screening services and sexual behavior[21, 22]. On the contrary, the lowest ASIR of cervical cancer observed in North Africa and Middle East, which might be due to cultural background and conservative sexual behaviors[23]. These regions also had low rates of other sexually related infections, such as HIV [24]. In general, decreasing trends in incidence of cervical cancer in most countries was observed, and the most obvious downward trend was Maldives, Taiwan and Singapore, due to cancer screening programs and HPV program financed by huge government expenditures. Those countries have launched national screening programs respectively, which greatly reduced cervical cancer risks, for example Maldives in 2014[25], Taiwan in 2004[26] and Singapore in 1995[27]. However, the increasing trends still appeared in some countries, particularly Lesotho, Italy, and China. Poverty, weak health systems, and low level of education still were stumbling blocks to Lesotho[28]. China is the largest 
population worldwide, also had the highest number of incidence, mortality and DALYs of cervical cancer[29], which may reflect the deficiency of Pap test in China[30]. Because of the overworking of public immunization systems, vaccination coverage in girls at age 15 years had decreased in Italian in recent years[31]. Besides, an online survey also reported that poor knowledge about HPV were found in Italian undergraduates [32].

The GBD study provided high quality assessment of cervical cancer based on the quality and quantity of data. However, this paper has some limitations: (1) in many low-income regions, due to different screening methods in different countries[33], vital registration and cancer registry data were poor and heterogeneous[30]. At the same time, there may be underestimation bias in these cancer registrations; (2) when the actual data of disease burden is not available, the uncertainty of GBD estimates fills the gap. In addition, in this analysis mode, differences in data collection and coding as well as data source quality are still inevitable[34].

\section{Conclusions}

The incidence, death and DALYs of cervical cancer showed decreasing trends at global, regional, and national level from 1990 to 2019 . However, the trends were relatively slow, and showed high regional imbalance. Consequently, cervical cancer is still a major public health problem, more effective prevention and management strategies should be developed.

\section{Abbreviations}

GBD: Global Burden of Disease; DALYs: Disability-adjusted life years; ASR: Age-standardized rate; Ul: Uncertainty interval; Cl: Confidence interval; EAPC: Estimated annual percentage change; GHDx: Global Health Data Exchange; SDI: Socio-demographic index.

\section{Declarations}

\section{Acknowledgments}

Thanks to the Institute for Health Metrics and Evaluation (IHME) and the Global Burden of Disease study collaborations.

\section{Authors' contributions}

Xingxing Zhang: Project administration and drafting.

Danfeng Yu: Data analysis and validation.

Wenwen Cai: Data analysis and visualization.

Weiqing Ruan:Supervision and drafting and editing. 
Xingxing Zhang and Danfeng Yu contributed equally to this manuscript.

All authors read and approved the final manuscript.

\section{Funding}

This work was supported by the Guangdong Technology and Science Planning Fund (NO: 2020A1414040014).

\section{Availability of data and materials}

All data during this study are included in this published article and its supplementary information files.

\section{Ethics approval and consent to participate}

Not applicable.

\section{Consent for publication}

All authors consent for publication of the manuscript.

\section{Competing interests}

The authors declare no competing interests.

\section{Author details}

${ }^{1}$ Nanfang Hospital,Southern Medical University, Guangzhou, Guangdong, China. ${ }^{2}$ Department of MICU, Guangdong Women and Children Hospital, Guangzhou, Guangdong, China.

\section{References}

1. Bray F, Ferlay J, Soerjomataram I, Siegel RL, Torre LA, Jemal A: Global cancer statistics 2018: GLOBOCAN estimates of incidence and mortality worldwide for 36 cancers in 185 countries. $C A$ Cancer J Clin 2018, 68(6):394-424.

2. Torre LA, Islami F, Siegel RL, Ward EM, Jemal A: Global Cancer in Women: Burden and Trends. Cancer Epidemiol Biomarkers Prev 2017, 26(4):444-457.

3. Arbyn M, Weiderpass E, Bruni L, de Sanjosé S, Saraiya M, Ferlay J, Bray F: Estimates of incidence and mortality of cervical cancer in 2018: a worldwide analysis. Lancet Glob Health 2020, 8(2):e191-e203.

4. Arbyn M, Castellsagué X, de Sanjosé S, Bruni L, Saraiya M, Bray F, Ferlay J: Worldwide burden of cervical cancer in 2008. Ann Oncol 2011, 22(12):2675-2686.

5. Atun R, Jaffray DA, Barton MB, Bray F, Baumann M, Vikram B, Hanna TP, Knaul FM, Lievens Y, Lui TY et al: Expanding global access to radiotherapy. Lancet Oncol2015, 16(10):1153-1186. 
6. Brisson M, Kim JJ, Canfell K, Drolet M, Gingras G, Burger EA, Martin D, Simms KT, Bénard É, Boily MC et al: Impact of HPV vaccination and cervical screening on cervical cancer elimination: a comparative modelling analysis in 78 low-income and lower-middle-income countries. Lancet 2020, 395(10224):575-590.

7. Hirte H, Kennedy EB, Elit L, Fung Kee Fung M: Systemic therapy for recurrent, persistent, or metastatic cervical cancer: a clinical practice guideline. Curr Oncol 2015, 22(3):211-219.

8. Levi F, Lucchini F, Negri E, Franceschi S, la Vecchia C: Cervical cancer mortality in young women in Europe: patterns and trends. Eur J Cancer 2000, 36(17):2266-2271.

9. Drolet M, Bénard É, Pérez N, Brisson M: Population-level impact and herd effects following the introduction of human papillomavirus vaccination programmes: updated systematic review and metaanalysis. Lancet 2019, 394(10197):497-509.

10. Syrjänen S, Shabalova IP, Petrovichev N, Kozachenko VP, Zakharova T, Pajanidi J, Podistov JI, Chemeris G, Sozaeva LG, Lipova EV et al: Human papillomavirus testing and conventional pap smear cytology as optional screening tools of women at different risks for cervical cancer in the countries of the former soviet union. J Low Genit Tract Dis 2002, 6(2):97-110.

11. Wang R, Pan W, Jin L, Huang W, Li Y, Wu D, Gao C, Ma D, Liao S: Human papillomavirus vaccine against cervical cancer: Opportunity and challenge. Cancer Lett 2020, 471:88-102.

12. Klemp Gjertsen M, Neilson AR, Freiesleben de Blasio B: NIPH Systematic Reviews: Executive Summaries. In: Cost-Effectiveness of Human Papillomavirus (HPV) Vaccination in Norway. edn. Oslo, Norway: Knowledge Centre for the Health Services at The Norwegian Institute of Public Health (NIPH) Copyright @22007 by The Norwegian Institute of Public Health (NIPH). 2007.

13. Liu Z, Jiang Y, Yuan H, Fang Q, Cai N, Suo C, Jin L, Zhang T, Chen X: The trends in incidence of primary liver cancer caused by specific etiologies: Results from the Global Burden of Disease Study 2016 and implications for liver cancer prevention. J Hepato/ 2019, 70(4):674-683.

14. Vu M, Yu J, Awolude OA, Chuang L: Cervical cancer worldwide. Curr Prob/ Cancer 2018, 42(5):457-465.

15. Crosbie EJ, Einstein MH, Franceschi S, Kitchener HC: Human papillomavirus and cervical cancer. Lancet 2013, 382(9895):889-899.

16. Who: Human papillomavirus vaccines: WHO position paper. Biologicals 2009, 37(5):338-344.

17. Gaffney DK, Hashibe M, Kepka D, Maurer KA, Werner TL: Too many women are dying from cervix cancer: Problems and solutions. Gynecol Oncol 2018, 151(3):547-554.

18. Janicek MF, Averette HE: Cervical cancer: prevention, diagnosis, and therapeutics. CA Cancer J Clin 2001, 51(2):92-114; quiz 115-118.

19. Mancuso P, Djuric O, Collini G, Serventi E, Massari M, Zerbini A, Giorgi Rossi P, Vicentini M: Risk of cancer in individuals with alcohol and drug use disorders: a registry-based study in Reggio Emilia, Italy. Eur J Cancer Prev 2020, 29(3):270-278.

20. Fitzmaurice C, Allen C, Barber RM, Barregard L, Bhutta ZA, Brenner H, Dicker DJ, Chimed-Orchir O, Dandona R, Dandona L et al: Global, Regional, and National Cancer Incidence, Mortality, Years of Life 
Lost, Years Lived With Disability, and Disability-Adjusted Life-years for 32 Cancer Groups, 1990 to 2015: A Systematic Analysis for the Global Burden of Disease Study. JAMA Onco/ 2017, 3(4):524-548.

21. Jemal A, Center MM, DeSantis C, Ward EM: Global patterns of cancer incidence and mortality rates and trends. Cancer Epidemiol Biomarkers Prev 2010, 19(8):1893-1907.

22. Wong CL, Choi KC, Law BMH, Chan DNS, So WKW: Effects of a Community Health Worker-Led Multimedia Intervention on the Uptake of Cervical Cancer Screening among South Asian Women: A Pilot Randomized Controlled Trial. Int J Environ Res Public Health 2019, 16(17).

23. Hamdi S: The impact of teachings on sexuality in Islam on HPV vaccine acceptability in the Middle East and North Africa region. J Epidemiol Glob Health 2018, 7 Suppl 1(Suppl 1):S17-s22.

24. Gökengin D, Doroudi F, Tohme J, Collins B, Madani N: HIV/AIDS: trends in the Middle East and North Africa region. Int J Infect Dis 2016, 44:66-73.

25. Basu P, Hassan S, Fileeshia F, Mohamed S, Nahoodha A, Shiuna A, Sulaiman Al, Najeeb N, Saleem FJ: Knowledge, attitude and practices of women in maldives related to the risk factors, prevention and early detection of cervical cancer. Asian Pac J Cancer Prev 2014, 15(16):6691-6695.

26. Chen YY, You SL, Chen CA, Shih LY, Koong SL, Chao KY, Hsiao ML, Hsieh CY, Chen CJ: Effectiveness of national cervical cancer screening programme in Taiwan: 12-year experiences. Br J Cancer 2009, 101(1):174-177.

27. Lim GH, Chow KY, Lee HP: Singapore cancer trends in the last decade. Singapore Med J 2012, 53(1):39; quiz 10.

28. Carroll KA, Pierce J, Kovarik CL: Perianal Bowen disease in a child with human immunodeficiency virus. Pediatr Dermatol 2010, 27(2):166-169.

29. Di J, Rutherford S, Chu C: Review of the Cervical Cancer Burden and Population-Based Cervical Cancer Screening in China. Asian Pac J Cancer Prev 2015, 16(17):7401-7407.

30. Chen W, Zheng R, Baade PD, Zhang S, Zeng H, Bray F, Jemal A, Yu XQ, He J: Cancer statistics in China, 2015. CA: a cancer journal for clinicians 2016, 66(2):115-132.

31. Bigaard J, Franceschi S: Vaccination against HPV: boosting coverage and tackling misinformation. $\mathrm{Mol}$ Oncol 2020.

32. Trucchi C, Amicizia D, Tafuri S, Sticchi L, Durando P, Costantino C, Varlese F, Silverio BD, Bagnasco AM, Ansaldi $\mathrm{F}$ et al: Assessment of Knowledge, Attitudes, and Propensity towards HPV Vaccine of Young Adult Students in Italy. Vaccines (Basel) 2020, 8(1).

33. Black E, Richmond R: Prevention of Cervical Cancer in Sub-Saharan Africa: The Advantages and Challenges of HPV Vaccination. Vaccines (Basel) 2018, 6(3).

34. Mikkelsen L, Phillips DE, AbouZahr C, Setel PW, de Savigny D, Lozano R, Lopez AD: A global assessment of civil registration and vital statistics systems: monitoring data quality and progress. Lancet 2015, 386(10001):1395-1406.

\section{Figures}




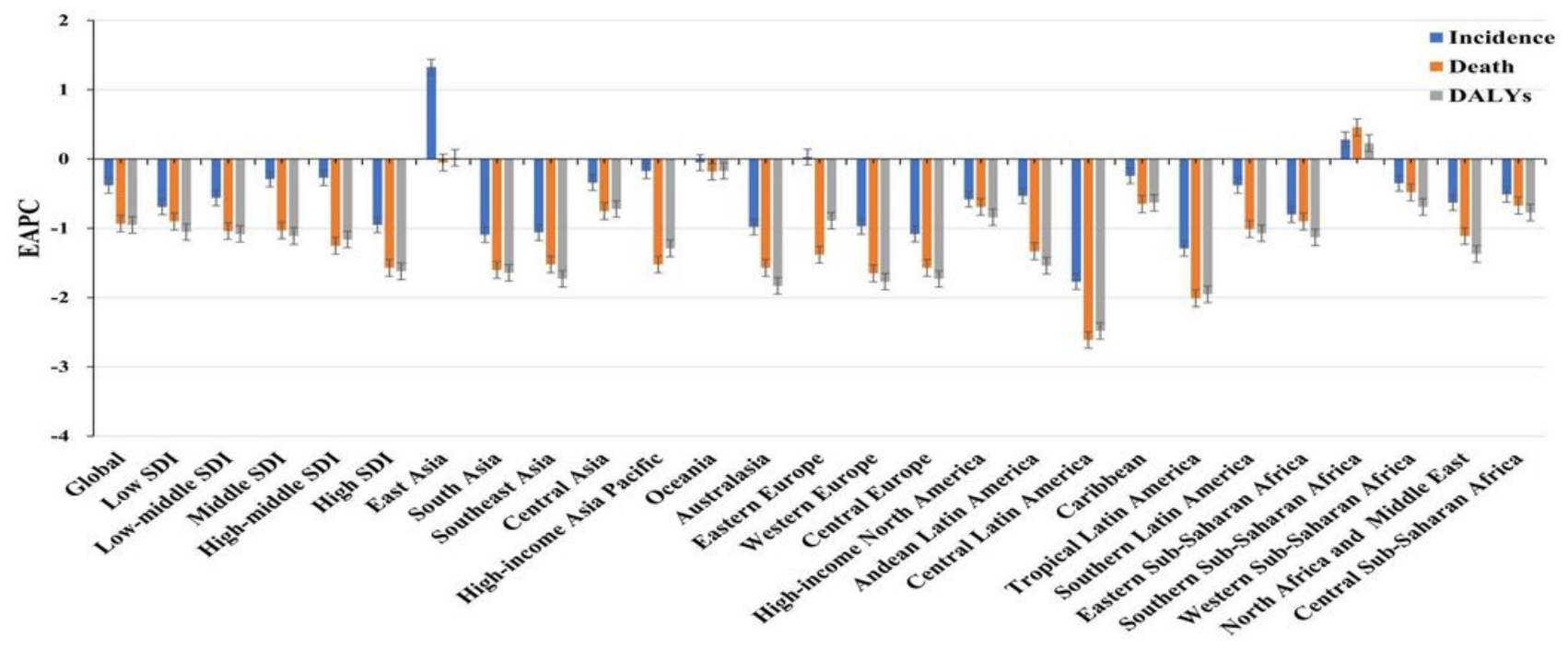

Figure 1

The trends in incidence, death, and DALYs of cervical cancer globally, and in SDI areas and geographic regions from 1990 to 2019. SDI, sociodemographic index; DALYs, disability-adjusted life years.

(A)

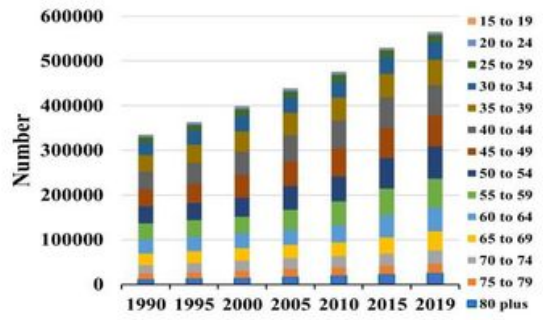

(B)

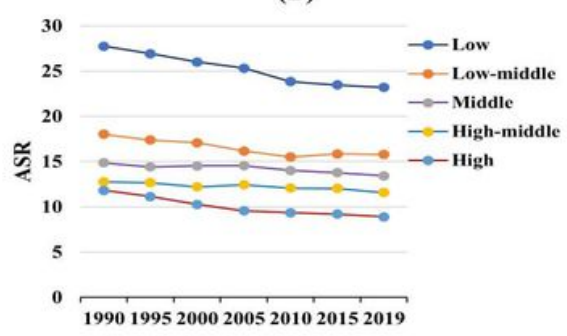

(C)

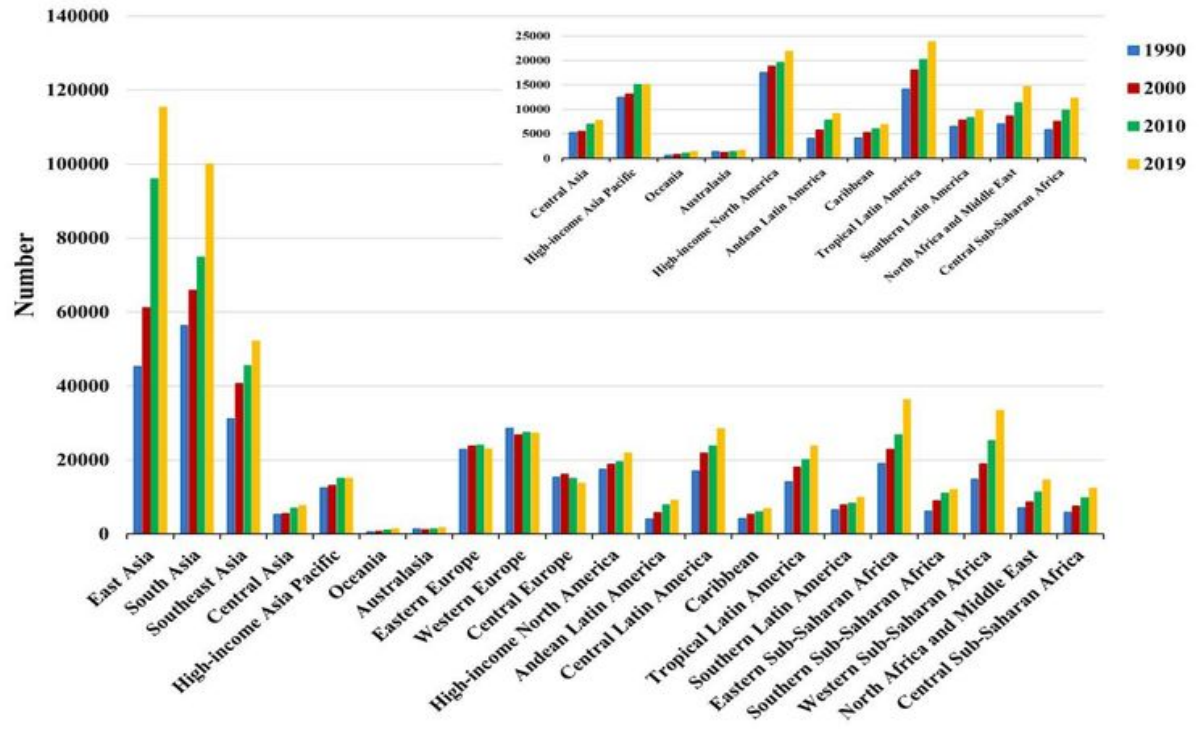

Figure 2

The distribution of the incident number of cervical cancer worldwide, and in SDI areas and geographic regions from 1990 to 2019. (A) the incident number in age groups; (B) the ASR in SDI areas; (C) the incident number in geographical regions. SDI, sociodemographic index; ASR, age-standardized rate. 

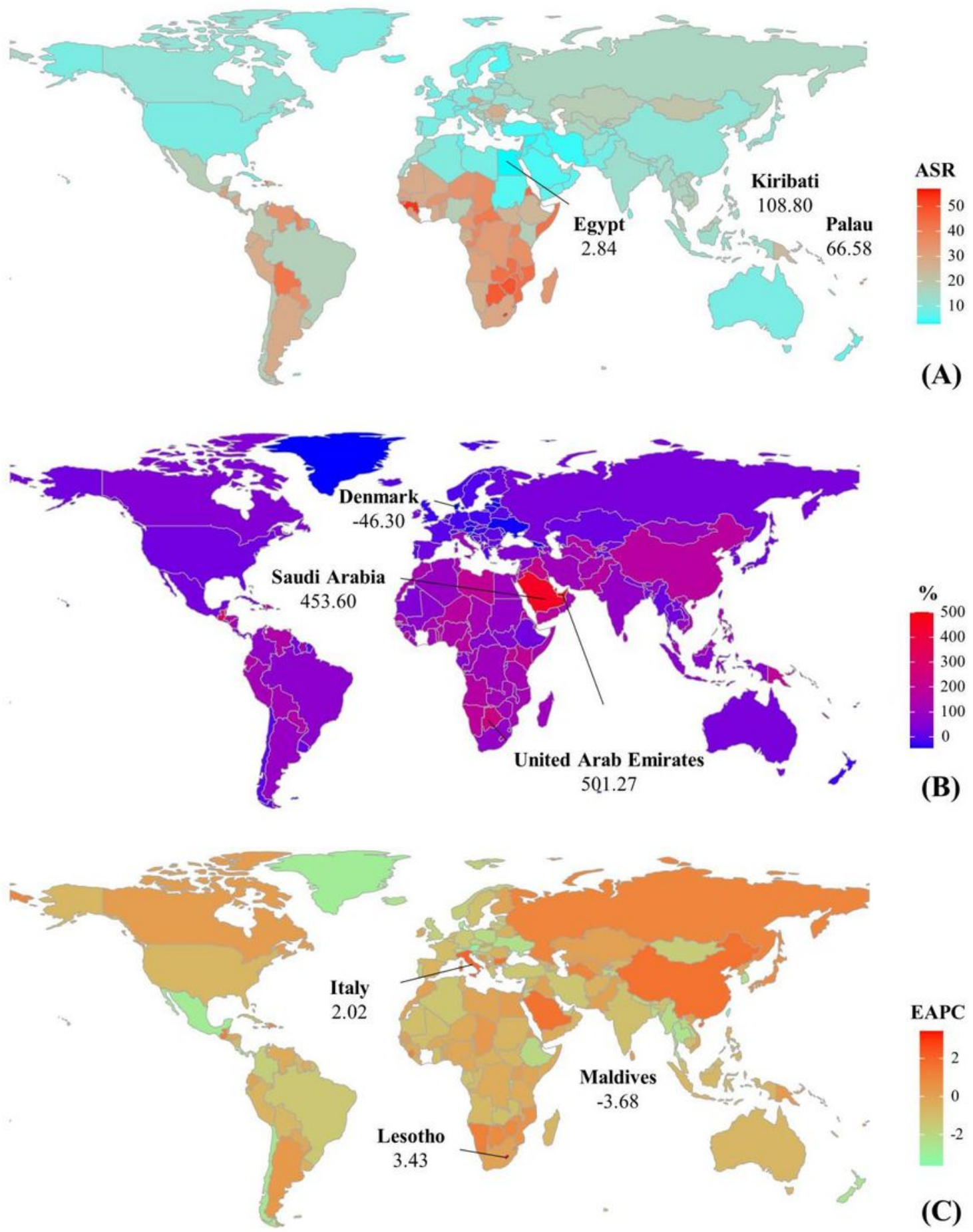

\section{Figure 3}

The distribution of ASR, percentage changes in number, and EAPCs of cervical cancer incidence at the national level, 1990-2019. The follows were (A) the ASR in 2019; (B) the percentage changes in number between 2000 and 2019; (C) the EAPCs in countries/territories, respectively. Countries/territories with an extreme value were annotated. ASR, age-standardized rate; EAPC, estimated annual percentage change. Note: The designations employed and the presentation of the material on this map do not imply the 
expression of any opinion whatsoever on the part of Research Square concerning the legal status of any country, territory, city or area or of its authorities, or concerning the delimitation of its frontiers or boundaries. This map has been provided by the authors.
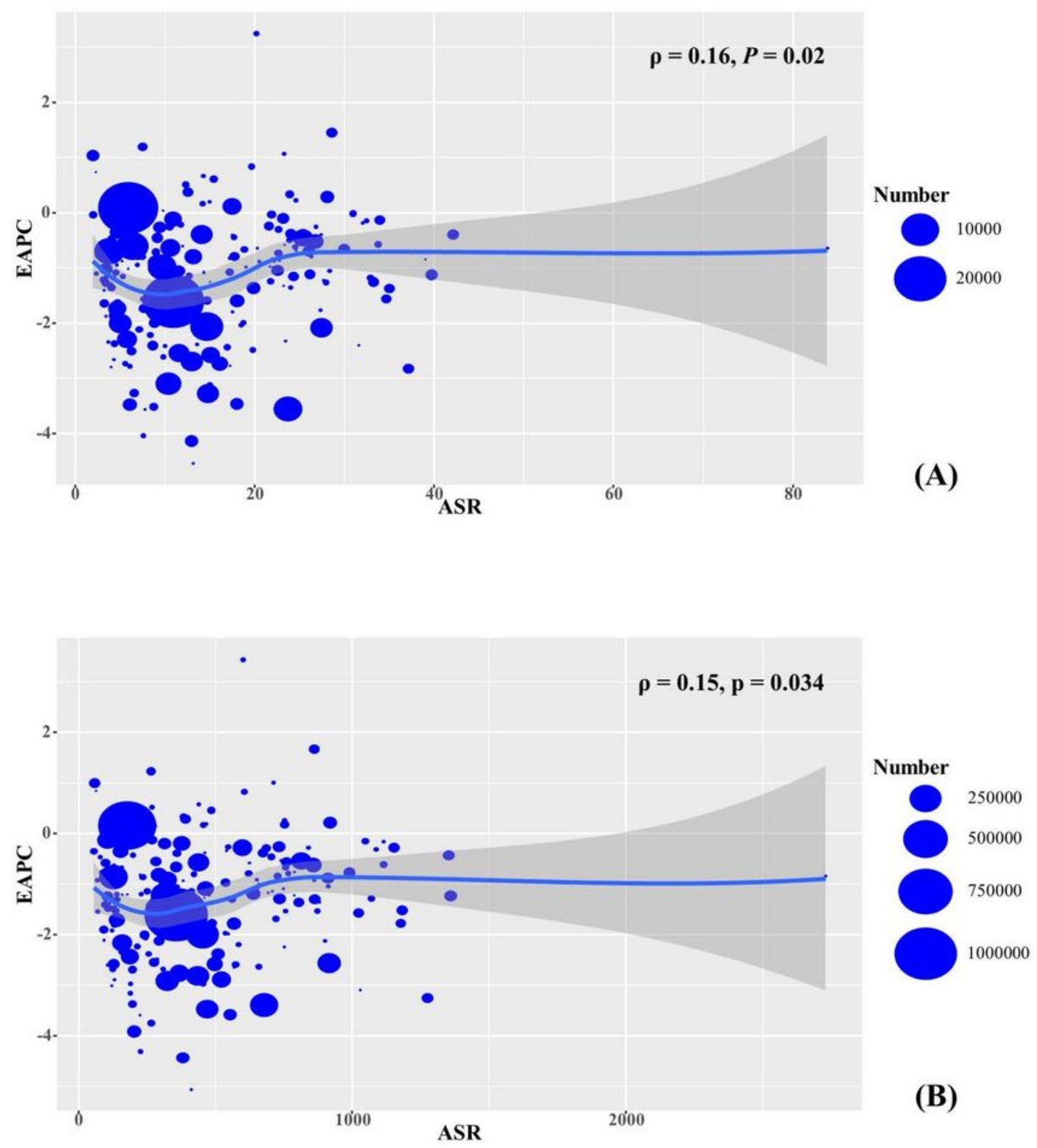

\section{Figure 4}

The correlation between EAPCs and ASR in 1990 at the national level. The EAPCs of death(A), and DALYs(B) had positive associations with ASR in 1990, respectively. The association was calculated with 
Pearson correlation analysis. The size of circle is increased with the numbers in 1990. EAPC, estimated annual percentage change; ASR, age-standardized rate. DALYs, disability-adjusted life years.
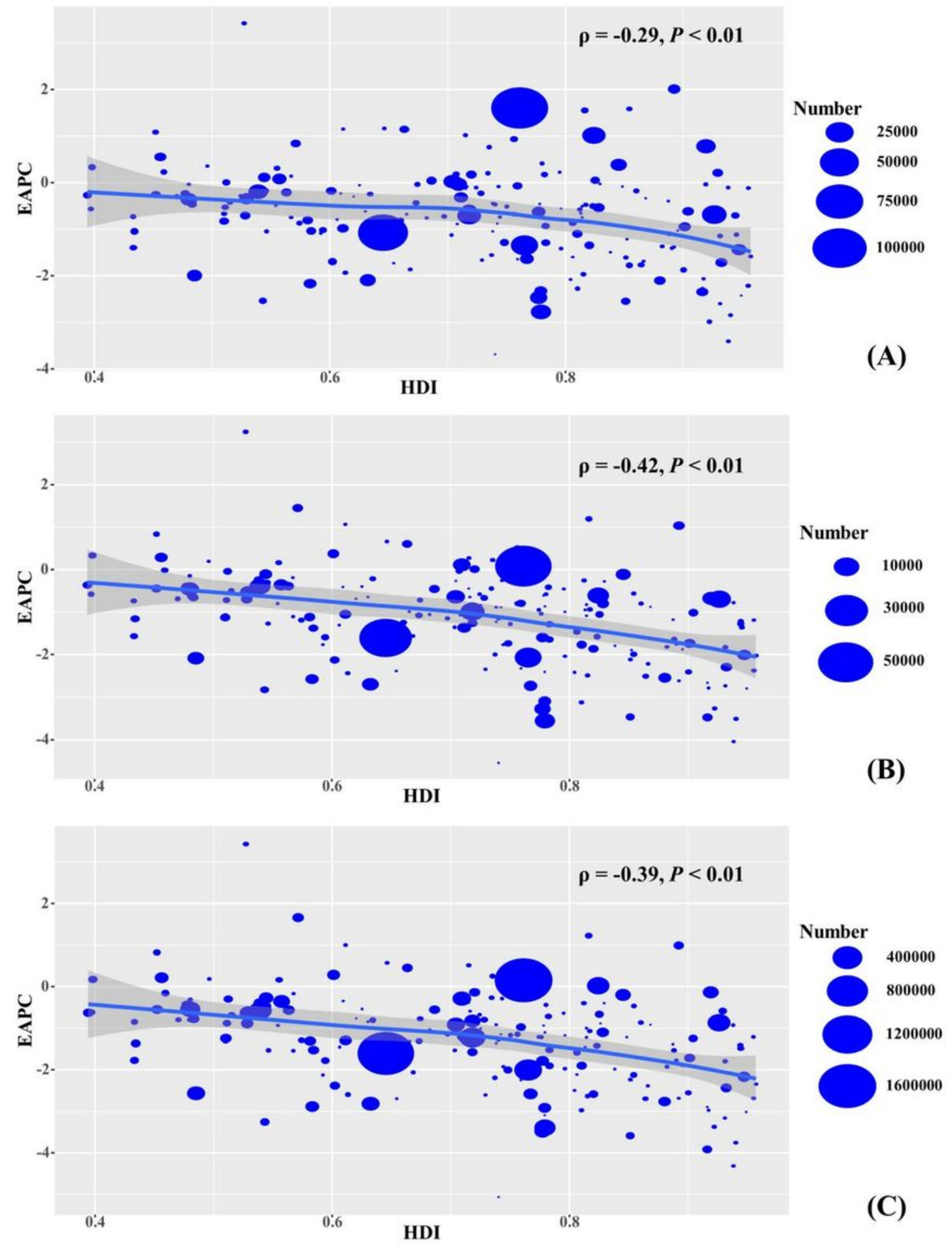

\section{Figure 5}

The correlation between EAPCs and HDI in 2019 at the national level. The EAPCs of incidence(A), death(B), and DALYs(C) had negative associations with HDI in 2019, respectively. The association was calculated 
with Pearson correlation analysis. The size of circle is increased with the numbers in 2019. EAPC, estimated annual percentage change; ASR, age-standardized rate. DALYs, disability-adjusted life years.

\section{Supplementary Files}

This is a list of supplementary files associated with this preprint. Click to download.

- Additionalfile1.doc

- Additionalfile2.doc

- Additionalfile3.doc

- Additionalfile4.doc

- Additionalfile5.doc

- Additionalfile6.doc

- Additionalfile7.doc

- Additionalfile8.doc

- Additionalfile9.doc

- Additionalfile10.doc 